\title{
Number of Prostate Tissue Cores Positive for Carcinoma
}

National Cancer Institute

\section{Source}

National Cancer Institute. Number of Prostate Tissue Cores Positive for Carcinoma. NCI Thesaurus. Code C148278.

An indication of the number of prostate core specimens that are identified as positive for carcinoma. 